\title{
Forest Resources in the Performance of Mexican Community Forest Enterprises in a Vertical Integration System
}

\section{Juan Regino Maldonado1 , Yali Wen² , Frederick Cubbage ${ }^{3}$, Patricia Regino Maldonado4}

\author{
${ }^{1}$ Department of Natural Resources, Instituto Politécnico Nacional-CIIDIR Oaxaca, Hornos 1003, Noche Buena, \\ Santa Cruz Xoxocotlan, Oaxaca \\ ${ }^{2}$ School of Economics and Management, Beijing Forestry University, China \\ ${ }^{3}$ Department of Forestry and Environmental Resources, North Carolina State University, USA \\ ${ }^{4}$ Department of industrial engineering, Universidad del Valle de México, Torreon-San Pedro 2155 km. 3.7, La \\ Unión, Coahuila, México
}

\begin{abstract}
The objective of the research was to analyze the relationship between the use and control of forest resources as measured by volume sold $\left(\mathrm{m}^{3} /\right.$ year), volume harvested $\left(\mathrm{m}^{3} / \mathrm{ha}\right)$, and timber production area under forest management (ha) and the performance as measured by profits $\left(\$ / \mathrm{m}^{3}\right)$ of community forest enterprises in Mexico under a vertical integration system, from perspectives theory of the firm and new institutional economics. The study is based on an analysis of data from a sampling of 30 enterprises in 12 states in the country in 2011. The research hypothesis states that the use and control of forest resources is positively associated with the profits of the enterprises. The study used linear regression to test the hypothesis. The study concludes that for the sample, the volume harvested $\mathrm{m}^{3} / \mathrm{ha}$, was associated positively and significantly with harvesting profits $\$ / \mathrm{m}^{3}$. Whereas, the timber production area (ha) and volume sold $\mathrm{m}^{3} /$ year were associated positively, but not significantly with profits $\$ / \mathrm{m}^{3}$ of enterprises. At the group level, the volume harvested $\mathrm{m}^{3} / \mathrm{ha}$ was positively associated with harvesting profits $\left(\$ / \mathrm{m}^{3}\right)$ of type III (timber growing and harvesting) enterprises, while volume sold $\left(\mathrm{m}^{3} /\right.$ year) was associated positively with harvesting profits $\left(\$ / \mathrm{m}^{3}\right)$ of type IV (vertically integrated timber growing through sawmilling) enterprises. The statistical results were not significant. This suggests no definite conclusions can be made on the general and by size, use and control of forest resources regression results. However, the results are a first approach to understanding the performance of enterprises vertically integrated under a structure of communal government.
\end{abstract}

Keywords: Community Forest Enterprises; Vertical Integration; New Institutional Economics; Theory Of The Firm; Resource-Based View; Common-Pool Resources

\section{Introduction}

Mexico is the fourth most mega-diverse country in the world and forest ecosystems are a major contributor to global diversity (SEMARNAT-INECC 2012). The country has about 65 million hectares of forest cover, which represents about 33\% of the country. This is composed of $95 \%$ natural forests (53\% primary and $42 \%$ secondary), and only $5 \%$ planted forests (FAO 2010). Of the total forest cover, around $60 \%$ is social property (ejido land and communal land) (Madrid et al. 2009). Where between 12 to 15 million poor people live and dependent of silviculture (Segura-Warnholtz 2014). According to Segura-Warnholtz (2014), in the country there were 15,859 forest communities, of which 2,380 manage their forests for commercial purposes. The forest communities can be associated to create economics units or community forest enterprises (CFEs), in the country there are around 992 CFEs (Cubbage et al. 2013). Which are classified as type I, II, III and IV; besides revenues for the commercialization of timber, they also derive revenues from non timber forest products, and from payment programs for environmental services, carbon sequestration, water capture and biodiversity conservation (CONAFOR 2010). In that sense, the CFE plays an important role in economic, social and environmental development on a local, national and global scale.

Among the first studies analyzing the performance of the CFE in a scheme of vertical integration were

This article is published under the terms of the Creative Commons Attribution License 4.0

Author(s) retain the copyright of this article. Publication rights with Alkhaer Publications.

Published at: http://www.ijsciences.com/pub/issue/2017-09/

DOI: 10.18483/ijSci.1163; Online ISSN: 2305-3925; Print ISSN: 2410-4477 
Antinori (2000), and Cubbage et al. (2013). In both studies, using profits as a performance measure, they concluded that most of the enterprises are profitable. Cubbage et al. (2013) found that the volume sold and the timber production area were relevant in the profits of the CFEs. Their study found that two variables (volume sold and timber production area) determined timber profitability for CFEs. Their extensive metadata from 2011 was published in a technical report, which has allowed us to examine other models and independent variables that could affect profitability.

Specifically, we examined a third variable-volume harvested - and integrated the three variables to refer to the use and control of forest resources (UCFR). The relationship between UCFR and CFE performance is thus analyzed. This paper also attempts to build a theoretical framework that supports and allows us to measure performance of CFEs. The study analyzes and discusses the contributions of the main theories of the firm regarding performance, such as a resource-based view and the structuralist theory. Then analyzes the data from Cubbage et al. (2013) to extend the integration of theory and CFE profitability further.

Given the peculiarity of the CFEs, which are under the tenure of ejido and communal land, or social property, contributions from new institutional economics about governance structure and the common-pool resources theory about property rights were analyzed. The governance structure and property rights in the commons enable the exchange and transfers of goods and services with the market. These determined the social, environmental and economic incentives and sanctions for breaches of agreements.

Thus, the study discusses the importance of institutions and property rights in the emergence of CFEs, in determining the organizational structure, and therefore also in the rules and regulations that govern the behavior and performance of these enterprises. First, we provide an introduction; second we discuss the theoretical and contextual framework; the third point explains the methodology; the fourth section presents the results of research; and last we present discussions and conclusions.

\section{Forest Sector in Mexico}

In Mexico during the period 2004-2013, forest timber production decreased steadily, from 6.7 million cubic meters roundwood (rolliza, $\mathrm{m}^{3} \mathrm{r}$ ) in 2004 to 5.9 million $\mathrm{m}^{3} \mathrm{r}$ in 2013. The main products obtained were $74.9 \%$ sawlogs; cellulosic sheet and plywood, poles, piles and andirons $13.8 \%$; and fuels $11.3 \%$. The main species used were: coniferous (pine and oyamel), 79.0\%; hardwoods (oak), 8.7\%; and tropical (precious and tropical common), 5.4\% (SEMARNAT
2014). Fifteen years ago, studies had identified 10.7 million hectares for the establishment of commercial forest plantations (CONAFOR 2001). However, during the 2007-2012 period, CONAFOR established and paid for only 155,203 hectares of commercial forest plantations (CONAFOR 2013). In the last five years, the forestry sector has contributed on average barely $0.3 \%$ to national GDP. In 2013, the trade balance deficit was 5.9 billion dollars US. Paper imports were the main contributor to the trade deficit, followed by wood products and cellulose. The main products imported were: lumber, plywood, fiberboard, and beadings and moldings. The main products exported were: other wooden manufactures, slats and moldings, as well as windows, doors and cellular wood.

\section{Performance of the Firm}

In general, the literature indicates a trend towards devolution of forest land to local communities (White and Martin 2002; Gómez and Méndez 2007; Putz et al. 2004; McDaniel 2003; Zhang et al. 2000; Shen et al. 2009). There is evidence that CFEs are emerging and evolving in different countries (Scherr, White and Kaimowitz 2003; Bray et al. 2006; Nolan 2001); some studies even show the positive impact of reforms to land tenure in forestry and local economies (Zhang et al. 2002; Changhai et al. 2014; Xie et al. 2013; Shen et al. 2013). In that sense, the CFE plays an important role in the countries' economic, social and environmental development. Therefore, public policy and investment are required to assist in the permanence and evolution of CFEs. As part of this effort, in-depth studies that reveal the strengths and weaknesses faced by the enterprises are required. This study examines elements of strategic resources in the performance of the CFE. Two conflicting models explain the performance of the firm: (1) the model of the resource-based view (RBV) (Barney 1991; 1986), and (2) the model of structuralist theory (ST) (Bain 1954; Porter 1985; 1980). The two previous theories are based on an analysis of the assumptions that are violated in the model of perfect competition or their failures. These strategic failures are considered beneficial to obtaining extra profits.

\section{Resource-Based View}

From the RBV, various manufacturing enterprise studies in developed countries show that internal firm factors better explain the performance compared to industry factors (Hawawini et al. 2003; Mauri and Michaels 1998; McGahan and Porter 1997; Rumelt 1991; Hansen and Wernelfelt 1989). Some studies have analyzed the effect of intangible resources as part of the internal factors of the firm's performance (Miller 2004; Schroeder et al. 2002; Yli-Renko et al. 2001). Studies of small, high-tech firms have reported similar results (Caloghirou et al. 2004; 
Mahemba and De Bruijn 2003; Wiklund and Shepherd 2003); as well as studies of small businesses in the service or retail sector trade (Brush and Changanti 1998; Bharadwaj et al. 1993). In particular, several studies in recent decades show that intangible resources such as knowledge were significantly related to performance of the firm (Hatch and Dyer 2004; McEvily and Chakravarthy 2002; Grant 1991; Hall 1993; 1992).

\section{Structuralist Theory}

The economics of industrial organization from the classical model structure-conduct-performance has made significant contributions in models of imperfect competition. Among those theories that have made contributions in models of imperfect competition are: transaction costs theory (Coase 1937; Williamson 1975); evolutionary theory of the firm (Reinganum 2005); theory of the firm (Holmstrom and Tirole 2005); noncooperative game theory (Fudenberg and Tirole 2005). These models have analyzed factors such as uncertainty, information asymmetries, bounded rationality, opportunism, asset specificity, vertical and horizontal integration, price discrimination, product differentiation, incomplete contracts, and strategic decisions in static and dynamic games with or without cooperation (Schmalensee and Willig 2005).

As regards performance of the firm from a ST point of view, early studies argued that the key factors in the performance were associated with high barriers to entry, the number and size of firms in the industry, product differentiation, vertical integration and concentration of suppliers; allowing for monopolistic practices (Bain 1954). Emphasis was placed on the relationship of market power and profitability. Some studies showed the efficiency of industry structure in the performance of the firm (Rumelt et al. 1991; Schmalensee 1985). Other studies showed that the size of the firm was associated with performance (Hall and Weiss 1967), while still others proved that the relationship between size and profitability was ambiguous (Prescott et al. 1986).

\section{Performance of CFEs from New Institutional Economics}

New institutional economics (NIE) suggests that in a world of high transaction costs, institutions determine the possibilities of exchange, such as incentive structure and the level of societal efficiency; the latter being the motivating factor of neoclassical economics (Coase 1960; North 1990). Per the classic approach of the Tragedy of the Commons (Hardin 1968), a system of open access to a common resource leads to overexploitation of natural resources. Thus, the study of the commons is relevant for an analysis of openaccess regimes or common property, and it is key to understanding the importance of institutions and the governance of natural resources (Ostrom 1990).

\section{Common-Pool Resources and Mexican CFE}

According to Schlager and Ostrom (1992), property rights that largely determine the government of the commons are: access and extraction (rights of use), management, exclusion and alienation (sale and control rights). The property rights of community forest land in Mexico began with the Mexican Revolution and were consolidated with the agrarian reforms of 1934-1940. They were not completed until the early nineties as a result of the reform of Article 27 of the Constitution and the Agrarian Law of 1992. These made explicit that community forest land should remain as common land, and thus inalienable (Segura-Warnholtz 2014). In 1992, the reform of Article 27 of the Mexican Constitution regulated land ownership and provided for the return of control of forest resources to the local communities (Muñoz-Piña et al. 2003). The new Agrarian Law of 1992 established the land tenure for private, ejido and communal property. These last two tenures of land are known as social or communal property (Merino-Pérez and Segura-Warnholtz 2005). An initial impact of the new agrarian law was the creation of forest enterprises known as "working groups" made up of individual landowners, under the legal category of Society of Rural Production (Wilshusen 2003).

The goal of the 1997 law was to deregulate the management of natural forests and introduce support for community forestry. It also regulated and continued to promote incentives for commercial plantations. It created the Support Program for the Development of Commercial Forest Plantations (PRODEPLAN for its acronym in Spanish), and the Forest Development Program (PRODEFOR for its acronym in Spanish). The first program had as its objective to develop productive projects, and the second to encourage the sustainable use of natural ecosystems. The Conservation and Sustainable Management of Forest Resources was created in 2001 (PROCYMAF for its acronym in Spanish), with the objective of promoting the strengthening of ejido and community organizations, as well as the construction and operation of CFEs (CONAFOR 2013).

In 2009, the program increased its budget to allow for more attention to communities; during this second stage it created the framework to build the typology of CFEs according to the level of its organizational capacities for the management natural resources, capitalization and level of vertical integration in the chain of forest production (Segura-Warnholtz 2014). Type I enterprises are those that have forest resources but do not perform management activities; type II 
enterprises sell their stumpage; type III enterprises have some forestry units and sell their roundwood; and type IV are those enterprises that transform natural resources and add value to products (SeguraWarnholtz 2014; Cubbage et al. 2013; CONAFOR 2013). In 2011, PROCYMAF was renamed The Community Forestry Development Program (PDFC for its acronym in Spanish), which promotes the technical training of forest advisors, processes of community organization and support for CFEs (CONAFOR 2013).

Thus the Agrarian Law of 1992 retained the forms of governance of the communities that were established during the Mexican Revolution, and were used to create CFEs (Antinori and Bray 2005). The Mexican case, they have generated a wide variety of institutional arrangements for managing the stock and flows of the common property resource and thus the structure of the CFE. CFEs are capable of generating an array of benefits for forest communities, including wages and benefits associated with employment, investment in public goods and welfare programs, direct profits sharing and capital investments in the CFE (Antinori and Bray 2005).

According to Bray et al. (2006) there are currently at least three types of models for CFEs in Mexico: (1) CFEs directly managed by community government through traditional governance practices, (2) communities where a clear division has been created between corporate governance and community governance through community boards and administrators, and (3) the dissolution of the single model of the CFE in subcommunal enterprises. However, although there are differences in the organizational structures of enterprises, the use of natural resources is collective.

In Mexico the democratization of natural resources through land reform contributed to the expansion of community forestry (Boyce and Shelly 2003). Also, some studies analyze the impact of the agrarian reform of 1992 and forest laws in the emergence of CFEs, as well as their impact on the consolidation of local institutions in the commons (Bray et al. 2006; Segura-Warnholtz 2014; Merino-Pérez and SeguraWarnholtz 2005). From the business perspective, very few studies have examined organizational factors and competitive strategies of the CFE. The studies Donovan et al. (2008); Stoian and Donovan (2010) of community rural enterprises in Latin America, the Caribbean, Asia and Africa which included Mexican CFEs found that they managed to accumulate physical capital, but show low levels of productivity and quality problems related to the production process. They conclude that most enterprises presented deficiencies in financial, social and human capital; however, they showed strengths in natural and physical capital. It is important to mention that the studies Donovan et al. (2008), Stoian and Donovan (2010) did not consider the differences between CFE and private forest enterprise, and the potential importance of such differences in performance. In fact, the study of Antinori and Bray (2005) argued that CFEs and common property community enterprises require extensions in the theory of the firm. CFEs as firms share similarities with other production organization, but also differ in important ways in terms of decision control, decision management, legal systems and objectives, mainly in land tenure and natural resources management. Since Mexico, has been historically in the vanguard in developing and relative mature sector of communities managing forest (Stone and D'Andrea 2001), it provides key elements for both a re-conceptualization of theories of the firm and empirical lessons about their institutional characteristics and economic benefits (Antinori and Bray 2005).

\section{Performance of Mexican CFE in a Vertical Integration System}

In the long-term economic performance of the CFE, it is key to maintain and expand the market. To do this, the enterprise has to implement competitive strategies with goals in the direction of the government of the commons (Antinori 2007). The organization of production involves contractual relations with the market, where individuals have to take the decision to make or buy (Coase 1937; Williamson 1981; 1975). The CFE decides to produce through vertical integration. According to Perry (2005), vertical integration may arise through: (1) vertical formation, when it is simultaneous with the creation of the firm, (2) vertical expansion, when it is a result of business growth, creating subsidiaries in neighboring processes, and (3) fusion, when it is a result of the acquisition of an existing enterprise in a neighboring process. In Mexico, according to Antinori (2000), in addition to the high transaction costs in the market, and the combined effect of three variables: (1) quantity and quality of forest resources, (2) production experience with concessionaires, and (3) collective experience in organization, increase the likelihood that a community will form a CFE and invest in the most advanced level of the production chain. The study Antinori and Rausser (2008) found that forest size is not only factor predicting vertical integration. Size and quality of the forest play a role in prediction but in combination with other factors. With certain levels organizational ability, communities with small-scale forests may also seek to vertically integrate. Parastatal leasing history, is an important predictor vertical integration for both small and large forests. General and forestry-specific skills, while it increases opportunity cost for local residents, also makes community integration more productive. Stock of logging roads tends to substitute for 
necessary specific investments and decreases the likelihood of community integration in extraction.

Considering the contributions of Perry (2005) and the findings of Antinori (2000), it can be said that vertical integration arises simultaneously with the creation of the CFE. That is, considering that the community had experience in the supply of raw material to the concessionary enterprises, collective experience in organizing and natural capital, the community decided to form the CFE and add value to the product. That way, the community is involved in transformation processes and commercialization, requiring them to develop technical, administrative and management skills. These skills evolved to the extent that strengthened each stage of the production chain. Thus, the stages of production are vertically integrated under the coordination of the firm.

Vertical integration takes shape under a structure of communal government, which defined the property rights of natural resources. Tirole (1989) note, the firm is vertically integrated, if it controls all decision taken by the vertical structure. That is, if the enterprise controls the totally production chain. Another important element to consider is vertical financial property or financial control, when the firm gets replace external financial transfers by internal transfers (Mahoney 1992). Up to this point, we are assuming that the vertical integration strategy of the CFE is based on the UCFR to control the production chain, and financial resources.

Antinori (2000) analyzed the performance of the CFE in Oaxaca, Mexico from the perspective of transaction costs. The sampling included integrated enterprises type I, II, III and IV. The study estimated profits as a measure of performance in the four stages of the production chain (forest management, harvesting, sawmilling and secondary products) based on production costs and revenues. She concludes that in the third stage of production, type III and IV enterprises had a higher profit margin in sawing (54\%). However, the study does not report profits by enterprise type given its state of integration in the production chain. This would allow one to know if the state of vertical integration to a lesser or greater level plays an important role in profits. Also, it is not known which factor or independent variables are_associated with profits. That way we could know which resources or set of resources are strategic in the performance of enterprises.

Cubbage et al. (2013) analyzed the competitiveness of type III and IV CFEs in Mexico; production cost was used as an indicator of competitiveness. The study estimates the costs of forest management, timber harvesting and sawmilling. That study collected data on timber production area under forest management (ha), volume harvested $\left(\mathrm{m}^{3} / \mathrm{ha}\right)$, volume sold $\left(\mathrm{m}^{3} /\right.$ year), and volume processed $\left(\mathrm{m}^{3} /\right.$ year $)$. It compared the production cost of the CFEs with production costs of enterprises from other countries, and found that Mexican CFEs operate with high costs.

They conclude that CFEs are not competitive in the international market. However, they report that Mexican CFEs perform well in the domestic market, given the high local prices of their products. The study also does not report the profits obtained by enterprise type as a function of the status of vertical integration. However, they argue that the volume sold $\mathrm{m}^{3} /$ year was negatively associated with production costs in $\$ / \mathrm{m}^{3}$, and positively associated with profits in $\$ / \mathrm{m}^{3}$. That is, an increase in volume sold causes lower production costs and increased profits. They also find that the timber production area (ha) was positively associated with production cost $\$ / \mathrm{m}^{3}$ and it was associated negatively with profits $\$ / \mathrm{m}^{3}$. An increase in the production area causes production cost increases and therefore decreases profits. Thus, Cubbage et al. (2013) argue that variables volume sold $\mathrm{m}^{3} /$ year and timber production area (ha) were relevant in the profits of the CFEs.

In summary, the two previous studies of CFEs and timber production did not report profits by type III and IV enterprises according to the state of vertical integration in the production chain. The state of vertical integration refers to the number of steps made by the enterprise in the production chain (Harrigan 1985; Restrepo 2007). Thus, it is known that type III enterprises perform three stages of production and type IV perform four. That is, the type IV enterprise has the highest level of vertical integration.

Thus this study attempted to analyze profits in type III and IV enterprises according to the state of their vertical integration in the production chain based on the data from Cubbage et al. (2013), who found that the volume sold and timber production area were the best independent variables for estimating the profits of the enterprise. In timber management and forest resources, the volume sold depends on the volume harvested, and the latter in turn depends on the timber production area. So, volume sold, volume harvested and timber production area should all affect the profits and use and control of forest resources (UCFR), so we extend the analysis by Cubbage et al. (2013) to test new hypotheses and models about CFE structure and returns.

Based on the analysis presented in this document, we can suppose that in the vertical integration of the enterprise, the UCFR plays a strategic role in performance in order to secure the supply of raw 
materials, and therefore assert control over the production and financial control. This way, the governance institutions of the commons determine the organizational structure of the enterprise, allow exchanges and transfers with the market, and establish incentive mechanisms and sanctions in the organization for production.

\section{The Study Area}

The selected CFEs are located in the states with the highest forest production in the country and are referred to in the literature as successful enterprises (Bray et al. 2006; Antinori and Bray 2005; Cubbage et al. 2013).

According to the similarity of the enterprises in terms of the composition of tree species, environmental characteristics and location, three regions were considered (Fig. 1). The northern region considered enterprises located in Chihuahua and Durango. The central region, enterprises located in Chiapas,
Guerrero, Jalisco, Mexico, Michoacán, Oaxaca, Puebla and Veracruz. The peninsular region, enterprises located in the states of Campeche and Quintana Roo; in this region, forests are categorized as tropical dry (Bray et al. 2005). Enterprises located in this region grow and sell precious wood and common hardwoods from tropical species. Mahogany (Swietenia spp.), which is considered to be a precious wood, is commercialized by enterprises. Cubbage et al. (2013) report lumber prices of mahogany ranging from 1,800 to $2,800 \$ / \mathrm{m}^{3}$, while the price of common hardwoods from 500 to $600 \$ / \mathrm{m}^{3}$. Both in the northern region and the central region, where forests are categorized as temperate natural forests, enterprises sell mainly pine (Pinus spp.) followed by oyamel (Abies spp.), and some enterprises take advantage of the oak to produce charcoal and or firewood (Quercus spp.). Pine lumber has a price ranging from 400 to $960 \$ / \mathrm{m}^{3}$, the oyamel from 630 to $800 \$ / \mathrm{m}^{3}$, while the oak from 70 to $600 \$ / \mathrm{m}^{3}$ (Cubbage et al. 2013).

Fig. 1 Map - Mexican community forest enterprises

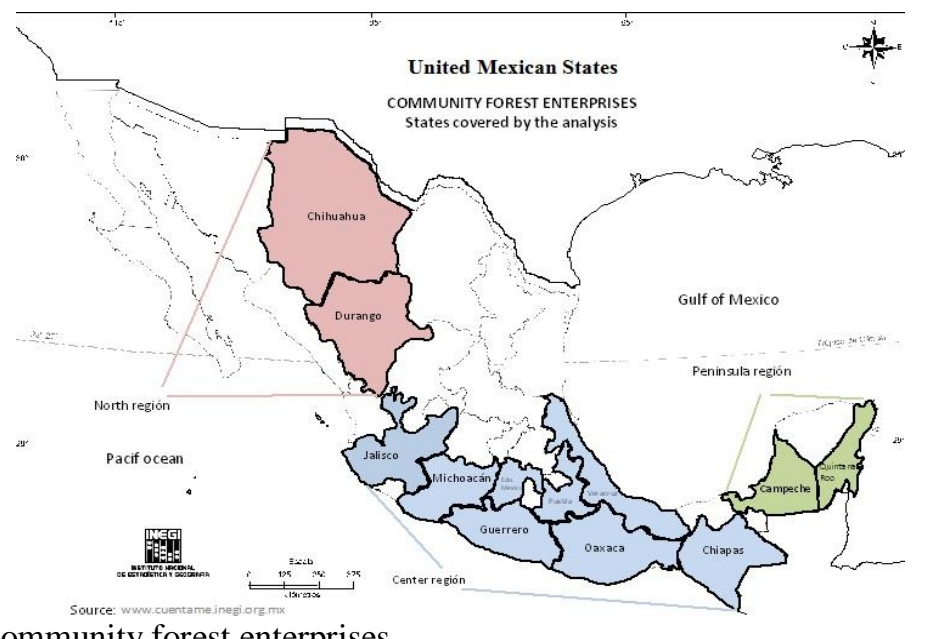

30 CFES were selected, whose sizes were determined according to the number of hectares under forest management production. Small enterprises with an area of less than 1,000 hectares of production, medium enterprises from 1,000 to 10,000 hectares and large enterprises greater than 10,000 hectares.
The group III type was composed of 2 small enterprises, 4 medium enterprises and 2 large enterprises. While the group IV type was composed of 7 small enterprises, 9 medium enterprises and 6 large enterprises (Table 1). 


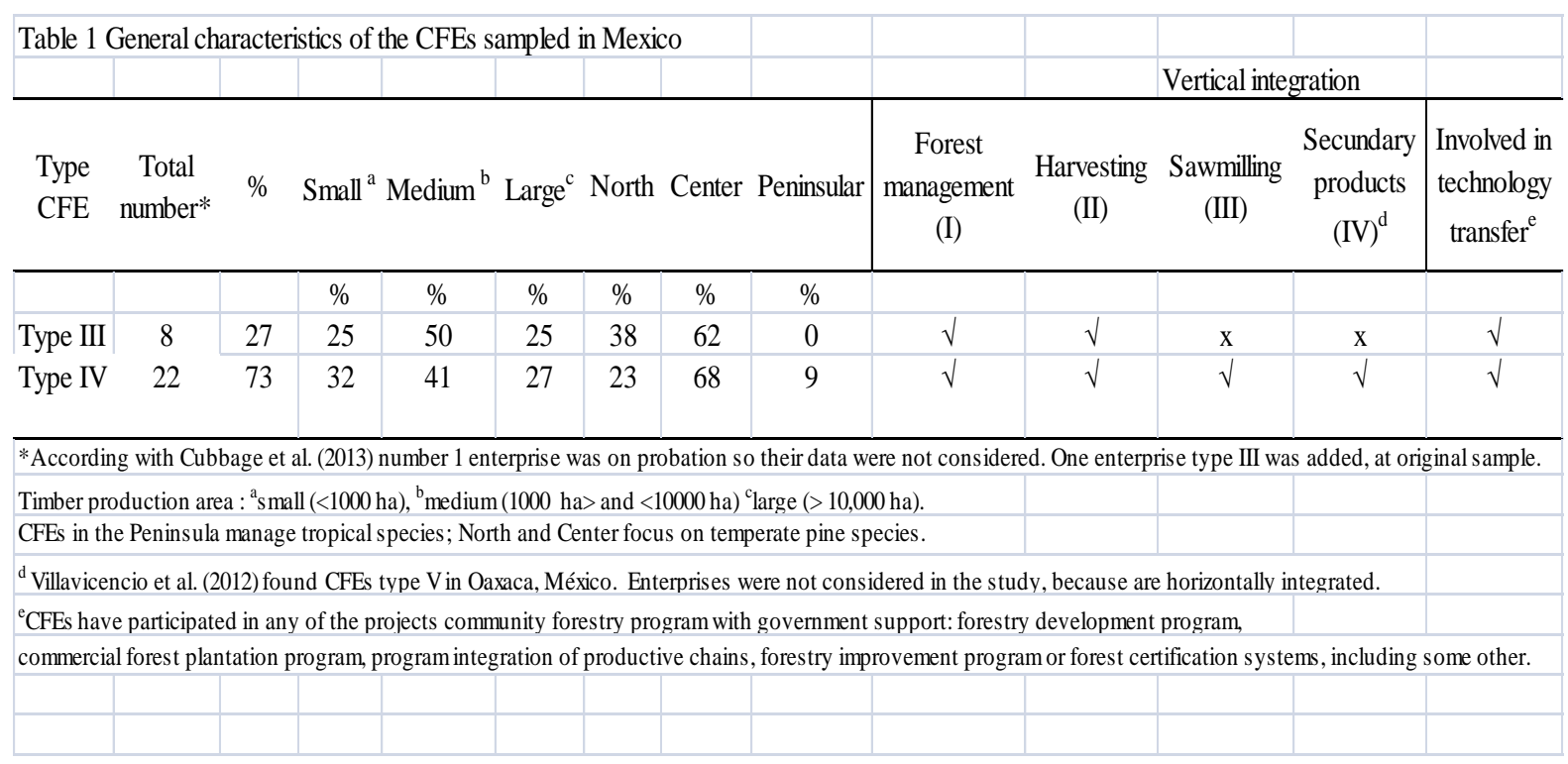

\section{Research Method}

According to CONAFOR (2010), in the country there were about 991 types I, II, III and IV CFEs. This study is quantitative; it is mainly based on the analysis of data from 30 sample CFEs in 12 states of Mexico in 2011 (Cubbage et al. 2013), out of a population of about 291 type III and IV enterprises. Types I and II were excluded, because those enterprises are in the lowest level of vertical integration of production chain.
The central question we examined was: what resource or strategic resources explain the performance of the CFE? We hypothesized that: the use and control of forest resources (UCFR) is positively associated with the profits of CFEs in a vertical integration system (Fig. 2). This provides a theoretical framework to examine the performance of CFEs as related to the key independent variables that were collected.

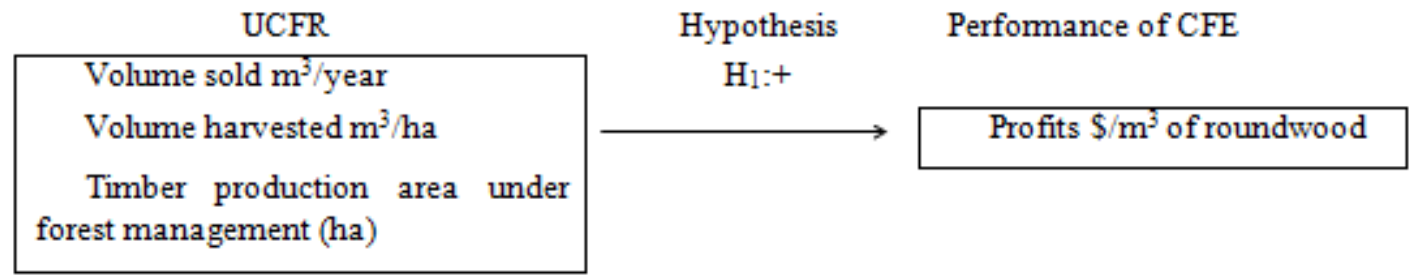

Fig. 2 Conceptual research model

To test the central hypothesis and answer the central research question, the sample was divided into two groups: one group of 22 type IV enterprises, and another group of 8 type III enterprises (Table 1). Statistical analyses were made to total sample level and at the group level in the following order: (1) the relationship between production costs and profits, (2) the relationship between UCFR and production costs, and finally to test the hypothesis and answer the research question, (3) the relationship between UCFR and profits was analyzed. The data was analyzed with SPSS 17. Statistical analyses as ANOVA, Pearson correlation, and finally a linear regression were made to test the hypothesis.

\section{Results}

\section{Descriptive Analysis and ANOVA}

We analyze the last two of four stages of the production chain (forest management and harvesting) (Table 1), and we also estimated mean values of the forest management costs $\$ / \mathrm{m}^{3}$, harvesting cost $\$ / \mathrm{m}^{3}$, harvesting profits $\$ / \mathrm{m}^{3}$ and harvesting profits annual \$/year (Table A2.1 and A3.2). Then, Harvesting profits $\$ / \mathrm{m}^{3}$ and harvesting profits annual \$/year were compared in the type III and IV enterprises.

The ANOVA (independent samples $t$ test) result indicated that there were no significant differences between (1) mean values of harvesting profits $\$ / \mathrm{m}^{3}$ enterprises type III and IV (144\$ and $262 \$$ respectively) nor in (2) mean values of harvesting profits annual \$/year enterprises type III and IV $(1,291,120$ and $3,525,821$ \$/year). This means that 
the profits of the two groups of enterprises were not statistically different, due to wide variations in profits that masked any differences that might have existed.

Given the preceding results, the next step was to do the same analysis, but now by size of CFE, in order to compare the profits of small enterprises, medium enterprises and large enterprises within the two groups. Due to some medium enterprises in the group III recorded lost in 2011 (Table A3.2), comparing the mean values of profits not was realized. Therefore, we only carried out the comparison of mean values of profits by size in enterprises of group IV. ANOVA showed (1) no significant differences between mean values of harvesting profits $\left(\$ / \mathrm{m}^{3}\right)$ for the three sizes CFEs. However, large enterprises had the biggest harvesting profits $\$ / \mathrm{m}^{3}\left(379 \$ / \mathrm{m}^{3}\right)$ and medium enterprises lower harvesting profits $\$ / \mathrm{m}^{3}\left(205 \$ / \mathrm{m}^{3}\right)$; even though the latter had the lowest forest management costs and harvesting cost of the group. (2) There were significant differences between mean values of annual harvesting profits $\left(\$ / \mathrm{m}^{3}\right)$ for large enterprises and small enterprises in this group IV type $(8,230,583$ and 1,629,338 \$/year respectively) (Table A3.2).

Table A2.1 Type III and IV CFEs. Forest management cost and profits, 2011. (Mean values)

\begin{tabular}{|c|c|c|c|c|c|c|c|c|c|c|c|}
\hline CFE & Size & $\begin{array}{c}\text { Number } \\
\text { CFE }\end{array}$ & $\begin{array}{c}\text { Timber } \\
\text { production } \\
\text { area (ha) }\end{array}$ & $\begin{array}{c}\text { Volume } \\
\text { harvested } \\
\left(\mathrm{m}^{3} / \text { year) }\right.\end{array}$ & $\begin{array}{c}\text { Volume } \\
\text { harvested } \\
\left(\mathrm{m}^{3} / \mathrm{ha}\right)\end{array}$ & $\begin{array}{c}\text { Forest } \\
\text { management } \\
\operatorname{cost}^{1}\left(\$ / \mathrm{m}^{3}\right)\end{array}$ & $\begin{array}{c}\text { Forest } \\
\text { management } \\
\text { income } \\
\left(\$ / \mathrm{m}^{3}\right)\end{array}$ & $\begin{array}{c}\text { Forest } \\
\text { management } \\
\text { profits }\left(\$ / \mathrm{m}^{3}\right)\end{array}$ & $\begin{array}{c}\text { Forest } \\
\text { management } \\
\text { cost (\$/year) }\end{array}$ & $\begin{array}{c}\text { Forest } \\
\text { management } \\
\text { income } \\
\text { (\$/year) }\end{array}$ & $\begin{array}{c}\text { Forest } \\
\text { management } \\
\text { profits } \\
\text { annual }^{2} \\
\text { (\$/year) }\end{array}$ \\
\hline \multicolumn{2}{|c|}{ Type IV Small } & 7 & 651.0 & $4,030.1$ & 7.8 & 231.4 & 731.7 & 500.3 & $765,076.4$ & $2,834,087.9$ & $2,069,011.4$ \\
\hline & Medium & 9 & $5,828.3$ & $13,181.1$ & 2.6 & 150.3 & 600.9 & 450.6 & $1,745,720.0$ & $7,887,287.0$ & $6,141,567.0$ \\
\hline & Big & 6 & $20,764.5$ & $20,151.3$ & 0.9 & 184.8 & 651.8 & 467.0 & $2,365,439.7$ & $12,263,765.7$ & $9,898,326.0$ \\
\hline & Mean & & $8,254.5$ & $12,170.4$ & 3.8 & 185.5 & 656.4 & 470.9 & $1,602,711.5$ & $7,473,036.0$ & $5,870,324.5$ \\
\hline \multicolumn{2}{|c|}{ Type III Small } & 2 & 451.0 & $4,556.0$ & 13.5 & 191.5 & 666.5 & 475.0 & $769,115.0$ & $3,079,969.0$ & $2,310,854.0$ \\
\hline & Medium & 4 & $2,368.0$ & $4,914.0$ & 2.4 & 341.3 & 649.5 & 308.3 & $1,407,610.3$ & $3,073,462.5$ & $1,665,852.3$ \\
\hline & Big & 2 & $13,956.5$ & $14,819.0$ & 1.7 & 215.6 & 744.8 & 529.2 & $1,950,785.6$ & $11,534,176.5$ & $9,583,391.0$ \\
\hline & Mean & & $4,785.9$ & $7,300.8$ & 5.0 & 272.4 & 677.6 & 405.2 & $1,383,780.3$ & $5,190,267.6$ & $3,806,487.4$ \\
\hline & Mean & & $7,329.5$ & $10,871.8$ & 4.1 & 208.7 & 662.1 & 453.3 & $1,544,329.8$ & $6,864,297.8$ & $5,319,967.9$ \\
\hline \multicolumn{12}{|c|}{${ }^{1}$ Forest management cost $\$ / \mathrm{m}^{3}$, considered volume harvested $\mathrm{m}^{3} / y$ ear. } \\
\hline \multicolumn{4}{|c|}{${ }^{2}$ (Profits $\left.\$ / \mathrm{m}^{3}\right)\left(\right.$ volume harvested $\mathrm{m}^{3} /$ year) } & & & & & & & & \\
\hline & & & & & & & & & & & \\
\hline
\end{tabular}

Table A3.2 Type III and IV CFEs. Harvesting cost and profits, 2011. (Mean values)

CFE Size Number Timber Volume Harvesting Production Harvesting Harvesting Harvesting Total Harvesting Harvesting CFE production sold $\operatorname{cost}^{1}\left(\$ / \mathrm{m}^{3}\right) \operatorname{cost}^{2}\left(\$ / \mathrm{m}^{3}\right)$ income profits $^{3} \quad \operatorname{cost}(\$ / y e a r)$ production income profits

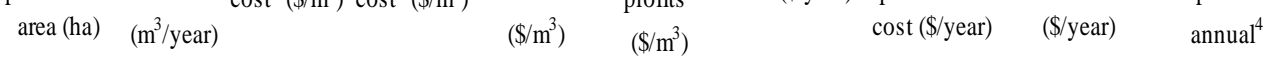
(\$/year)

\begin{tabular}{|c|c|c|c|c|c|c|c|c|c|c|c|}
\hline Type IV Small & 7 & 651.0 & $3,348.0$ & 516.1 & 747.6 & 982.1 & 234.6 & $956,678.1$ & $1,596,032.7$ & $3,225,370.9$ & $1,629,338.1^{*}$ \\
\hline Medium & 9 & $5,828.3$ & $9,309.6$ & 475.1 & 625.4 & 830.6 & $205.1^{*}$ & $4,290,837.0$ & $5,555,323.7$ & $7,419,679.7$ & $1,864,356.0$ \\
\hline Big & 6 & $20,764.5$ & $16,723.8$ & 492.3 & 677.2 & $1,055.8$ & $378.6^{*}$ & $4,279,071.3$ & $6,255,973.8$ & $14,486,556.3$ & $8,230,582.5^{*}$ \\
\hline Mean & & $8,254.5$ & $9,434.8$ & 492.9 & 678.4 & 940.2 & $261.8^{*}$ & $3,226,759.5$ & $4,486,635.7$ & $8,012,456.9$ & $3,525,821.1^{*}$ \\
\hline
\end{tabular}

\begin{tabular}{|c|c|c|c|c|c|c|c|c|c|c|c|}
\hline Type III Small & 2 & 451.0 & $3,536.5$ & 230.0 & 421.5 & 838.5 & 417.0 & $774,640.0$ & $1,346,966.0$ & $3,066,161.5$ & $1,719,195.5$ \\
\hline Medium & 4 & $2,368.0$ & $3,766.8$ & 578.0 & 919.3 & 924.8 & $5.5+$ & $1,949,093.8$ & $3,030,189.8$ & $3,382,966.8$ & $352,777.0$ \\
\hline Big & 2 & $13,956.5$ & $10,814.9$ & 547.5 & 763.1 & 909.4 & 146.3 & $5,593,946.9$ & $6,986,683.0$ & $9,726,412.0$ & $2,739,729.0$ \\
\hline Mean & & $4,785.9$ & $5,471.2$ & 483.4 & 755.8 & 899.3 & $143.5^{*}$ & $2,566,693.6$ & $3,598,507.1$ & $4,889,626.8$ & $1,291,119.6^{*}$ \\
\hline Mean & & $7,329.5$ & $8,377.8$ & 490.3 & 699.0 & 929.3 & 230.3 & $3,050,741.9$ & $4,249,801.4$ & $7,179,702.2$ & $2,929,900.8$ \\
\hline
\end{tabular}

${ }^{1}$ Harvesting cost $\$ / \mathrm{m}^{3}$, considered volume sold $\mathrm{m}^{3} / \mathrm{year}$.

${ }^{2}$ Include forest management cost and harvesting cost (not include transportation cost).

${ }^{3}$ Price in road (less forest management cost and harvesting cost $\$ / \mathrm{m}^{3}$ ).

${ }^{4}$ (Profits $\$ / \mathrm{m}^{3}$ )(volume sold $\mathrm{m}^{3} /$ year).

$\uparrow$ Some enterprises had lost. 


\section{Pearson's Correlation Analysis}

At the total sample level, production costs were related negatively and significantly with the harvesting profits $\left(\$ / \mathrm{m}^{3}\right) \quad(-.820, p<.01)$. In particular, forest management cost $\left(\$ / \mathrm{m}^{3}\right)$ and harvesting costs $\left(\$ / \mathrm{m}^{3}\right)$, were negatively and significantly correlated with harvesting profits $\left(\$ / \mathrm{m}^{3}\right)$ $(-.642, p<0.01$ and $-.763, p<.01$, respectively). Also volume sold $\left(\mathrm{m}^{3} /\right.$ year $)$ was associated negatively and significantly with production costs (\$/year) (-.424, p $<.05)$, and positively with harvesting profit $\left(\$ / \mathrm{m}^{3}\right)$ $(.244)$. The volume harvested $\left(\mathrm{m}^{3} / \mathrm{ha}\right)$ was negatively correlated with production costs $\left(\$ / \mathrm{m}^{3}\right)(-.267)$, and positively with harvesting profits $\left(\$ / \mathrm{m}^{3}\right)(.266)$. The timber production area (ha) was negatively correlated with production costs $\left(\$ / \mathrm{m}^{3}-\right)(-.115)$, and positively with harvesting profits $\left(\$ / \mathrm{m}^{3}\right)(.153)$ (Table 4).

Correlation analysis indicated that an increase in volume sold $\left(\mathrm{m}^{3} /\right.$ year $)$, volume harvested $\left(\mathrm{m}^{3} / \mathrm{ha}\right)$ and timber production area (ha) were associated with reduced production costs $\left(\$ / \mathrm{m}^{3}\right)$ and increased harvesting profits $\left(\$ / \mathrm{m}^{3}\right)$. To examine these findings, we carried out the linear regression analysis next using the same variables.

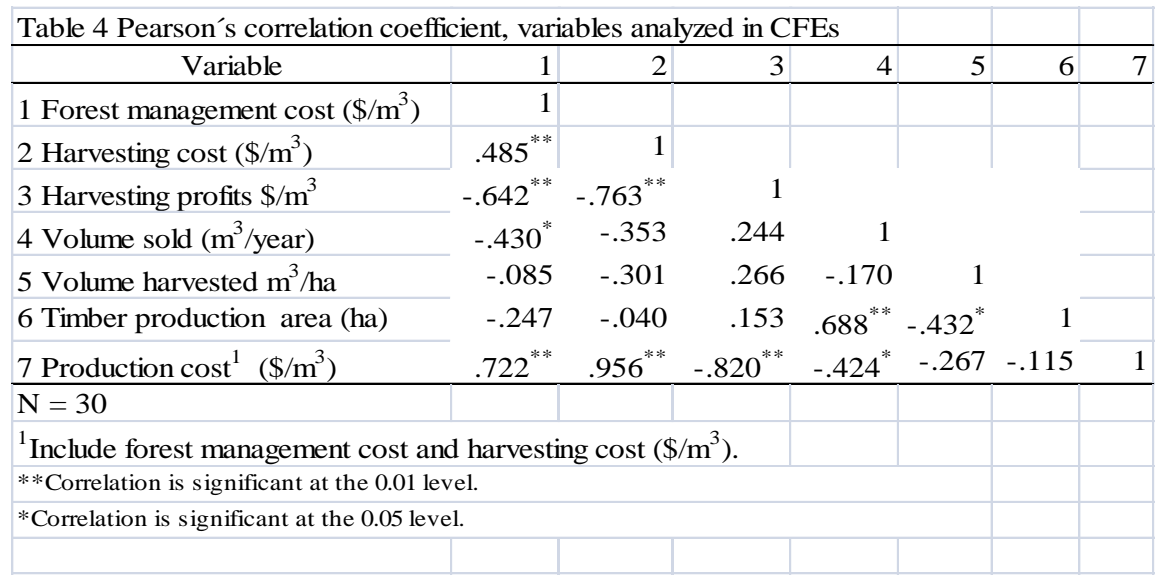

\section{Linear Regression Analysis}

Production costs and harvesting profits. The results of the linear regression indicated that at total sample level shows the forest management cost $\left(\$ / \mathrm{m}^{3}\right)$ and harvesting cost $\left(\$ / \mathrm{m}^{3}\right)$ were associated negatively and significantly with the harvesting profits $\$ / \mathrm{m}^{3}(\beta=-$ 1.136, $p<.01$ and $\beta=-.805, p<.01$, respectively) (Table 5). At the group III and IV level, the harvesting cost $\left(\$ / \mathrm{m}^{3}\right)$ was negatively and significantly greater importance than the forest management cost $\left(\$ / \mathrm{m}^{3}\right)$ in harvesting profits $\left(\$ / \mathrm{m}^{3}\right)$ in the two groups of enterprises $(\beta=-1.013, p<.01$ and $\beta=-.791, p<.01$, respectively). The group IV CFEs had lower average production costs $\left(\$ / \mathrm{m}^{3}\right)$ than the group III type $\left(678 \$ / \mathrm{m}^{3}\right.$ and $756 \$ / \mathrm{m}^{3}$, respectively); also group IV had higher average harvesting profits $\left(\$ / \mathrm{m}^{3}\right)$ than group III $\left(262 \$ / \mathrm{m}^{3}\right.$ and $144 \$ / \mathrm{m}^{3}$, respectively) (Table A3.2).

The harvesting cost in $\$ / \mathrm{m}^{3}$ was higher than the forest management cost in $\$ / \mathrm{m}^{3}$ in both groups. However, it was slightly higher in the group IV type. Harvesting profits in $\$ / \mathrm{m}^{3}$ were not only associated with decreasing production cost $\$ / \mathrm{m}^{3}$, but apparently with harvesting income $\$ / \mathrm{m}^{3}$ (price). In the same type IV group; large enterprises received an average harvesting income of $1,056 \$ / \mathrm{m}^{3}$ of wood, while medium enterprises received an average harvesting income of $831 \$ / \mathrm{m}^{3}$.

\begin{tabular}{|c|c|c|c|c|c|c|c|c|c|c|c|c|c|c|c|}
\hline \multicolumn{16}{|c|}{ Table 5 Linear regression analysis CFEs. Production cost $(\$ / \mathrm{m} 3)$ and harvesting profits $(\$ / \mathrm{m} 3)^{\mathrm{a}}$} \\
\hline Variable & Type III & & & & & Type IV & & & & & General & & & & \\
\hline & Coefficient & Std. error & $\mathrm{t}$ & Sig. & VIF & Coefficient & Std. error & $\mathrm{t}$ & Sig. & VIF & Coefficient & Std. error & $\mathrm{t}$ & Sig. & VIF \\
\hline Constant & 822.338 & 55.672 & 14.771 & .000 & & 878.638 & 137.540 & 6.388 & .000 & & 861.853 & 98.722 & 8.730 & .000 & \\
\hline Forest management cost $\$ / \mathrm{m}^{3}$ & -.695 & .263 & -2.638 & .046 & 2.615 & -1.222 & .606 & -2.017 & .058 & 1.203 & -1.136 & .400 & -2.842 & .008 & 1.308 \\
\hline Harvesting cost $\$ / \mathrm{m}^{3}$ & -1.013 & .155 & -6.552 & .001 & 2.615 & -.791 & .214 & -3.692 & .002 & 1.203 & -.805 & .170 & -4.730 & .000 & 1.308 \\
\hline $\mathrm{N}$ & 8 & & & & & 22 & & & & & 30 & & & & \\
\hline Adjusted $R^{2}$ & .97 & & & & & 0.56 & & & & & 0.65 & & & & \\
\hline Durbin-Watson & 2.193 & & & & & .866 & & & & & 1.204 & & & & \\
\hline \multicolumn{16}{|c|}{${ }^{2}$ Dependent variable, harverting profits $\$ / \mathrm{m}^{3}$. } \\
\hline & & & & & & & & & & & & & & & \\
\hline
\end{tabular}

UCFR and production costs. At the total sample level, volume sold $\left(\mathrm{m}^{3} /\right.$ year $)$ was associated negatively and significantly with the production cost
$\$ / \mathrm{m}^{3}(\beta=-.033, \mathrm{p}<.01)$; and the timber production area under forest management was associated positively with production cost $\left(\$ / \mathrm{m}^{3}\right)$ but not 
significantly $(\beta=.017)$ (Table 6$)$. At the group level, in the group IV type, volume sold in $\mathrm{m}^{3} /$ year was negatively and significantly associated with the production cost $\left(\$ / \mathrm{m}^{3}\right)(\beta=-.030, \mathrm{p}<.01)$, and in the group III type, volume sold ( $\mathrm{m}^{3} /$ year) was negatively associated with the production cost $\left(\$ / \mathrm{m}^{3}\right)$ but not significantly $(\beta=-.137)$.

In the group III and IV types, the timber production area under forest management was positively associated with the production cost in $\$ / \mathrm{m}^{3}$ but not significantly $(\beta=.078$ and $\beta=.016$, respectively). In fact, average enterprises of the group IV type sold more $\mathrm{m}^{3} /$ year of wood than the group III type $(9,435$ $\mathrm{m}^{3} /$ year and $5,471 \mathrm{~m}^{3} /$ year, respectively), with a relatively lower average production cost per $\mathrm{m}^{3}$ of timber than the group III type $\left(678 \$ / \mathrm{m}^{3}\right.$ and 756 $\$ / \mathrm{m}^{3}$, respectively) (Table A.3.2). The same group IV type has on average more timber production area under forest management than group III type $(8,255$ ha and 4,786 ha, respectively). The results of the linear regression suggest that the volume sold $\left(\mathrm{m}^{3} /\right.$ year) reduced production costs $\left(\$ / \mathrm{m}^{3}\right)$ in the two groups of enterprises. However, it was more significant in the group IV type.

\begin{tabular}{|c|c|c|c|c|c|c|c|c|c|c|c|c|c|c|c|}
\hline \multicolumn{16}{|c|}{ Table 6 Linear regression analysis.Use and control forest resources and production cost $(\$ / \mathrm{m} 3)^{\mathrm{a}}$} \\
\hline \multirow{2}{*}{ Variable } & Type III & & & & & Type IV & & & & & General & & & & \\
\hline & Coefficient & Std. error & $\mathrm{t}$ & Sig. & $\mathrm{VIF}$ & Coefficient & Std. error & $\mathrm{t}$ & Sig. & VIF & Coefficient & Std. error & $\mathrm{t}$ & Sig. & VIF \\
\hline Constant & 1132.926 & 324.584 & 3.490 & .017 & & 832.019 & 122.336 & 6.801 & .000 & & 844.292 & 102.750 & 8.217 & .000 & \\
\hline Volume sold $\mathrm{m}^{3} /$ year & -.137 & .097 & -1.416 & .216 & 8.115 & -.030 & .011 & -2.653 & .016 & 1.726 & -.033 & .011 & -2.837 & .009 & 1.899 \\
\hline Timber production area (ha) & .078 & .060 & 1.288 & .254 & 8.115 & .016 & .013 & 1.234 & .232 & 1.726 & .017 & .012 & 1.456 & .157 & 1.899 \\
\hline $\mathrm{N}$ & 8 & & & & & 22 & & & & & 30 & & & & \\
\hline Adjusted $\mathrm{R}^{2}$ & .002 & & & & & 0.21 & & & & & .183 & & & & \\
\hline Durbin-Watson & 2.556 & & & & & 2.416 & & & & & 2.568 & & & & \\
\hline
\end{tabular}

${ }^{a}$ Dependent variable, production cost (include forest management cost and harvesting $\cos t \$ / \mathrm{m}^{3}$ ).

UCFR and harvesting profits. The results of the linear regression tested the central hypothesis of the study. Namely, did the use and control of forest resources (UCFR) as measured by volume sold $\left(\mathrm{m}^{3} /\right.$ year $)$, volume harvested $\left(\mathrm{m}^{3} / \mathrm{ha}\right)$, and timber production area under forest management (ha) determine the performance and profits of CFEs?

At the total sample level, the volume harvested $\left(\mathrm{m}^{3} / \mathrm{ha}\right)$, was associated positively and significantly with harvesting profits $\left(\$ / \mathrm{m}^{3}\right)$. Therefore, it was the most important in explaining performance of CFEs $(\beta$ $=33.643, p<.01)$. Timber production area under forest management (ha) and Volume sold $\left(\mathrm{m}^{3} /\right.$ year), in that order were associated positively but not significantly with harvesting profits $\left(\$ / \mathrm{m}^{3}\right)(\beta=.011$ and $\beta=.009$, respectively) (Table 7).
At the CFE group level, in order of importance, the volume harvested $\left(\mathrm{m}^{3} / \mathrm{ha}\right)$ was associated positively but not significantly with harvesting profits $\left(\$ / \mathrm{m}^{3}\right)$ of type group III $(\beta=31.300)$; while volume sold $\left(\mathrm{m}^{3} /\right.$ year $)$ was associated positively and not significantly with the type IV group's profits $(\beta=$ .014). In general, the statistical tests were not significant and the statistical results were very low, which suggests not definite conclusions can be made on the general UCFR regression results (e.g., all adjusted $\mathrm{R}^{2}$ less than 0.08 , and only one significant variable (volume harvested per ha for only the general case)). However, the results are a first approach to understanding the performance of CFEs vertically integrated.

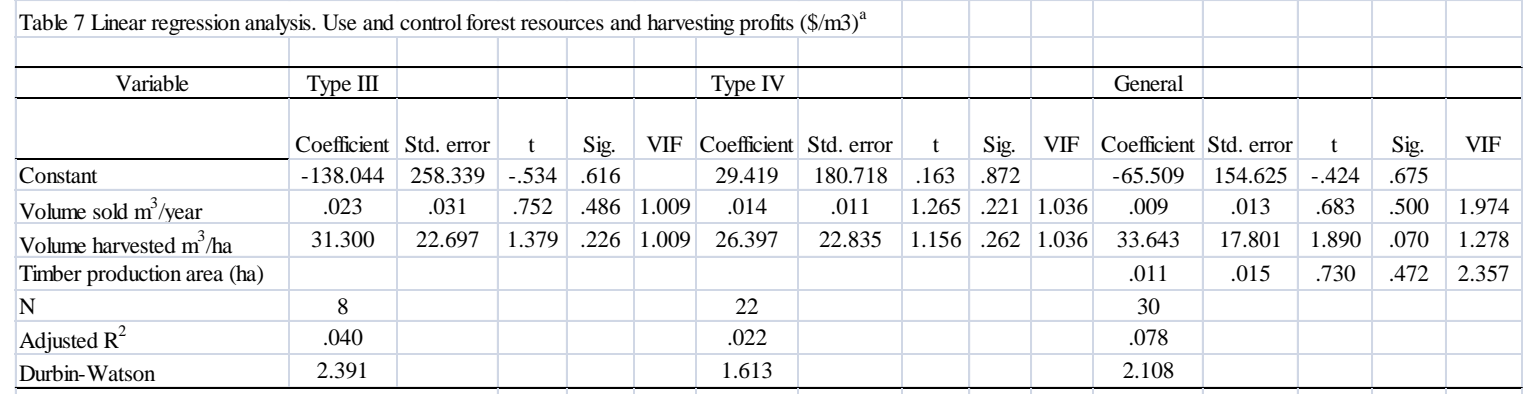

${ }^{\mathrm{a}}$ Dependent variable, harvesting profits $\$ / \mathrm{m}^{3}$.

\section{Discussion}

CFE group IV type had a higher level of vertical integration than the group III type; group IV's higher level of enterprises allow them to have a broader range of experience in mechanical work (Antinori and Bray 2005). The group IV type produces 
secondary products with higher added value (fourth stage production chain), as compared to the sawmilling production accruing to type group III (third stage production chain). Antinori (2000) found that state level CFEs in Oaxaca, Mexico obtained a $39 \%$ profit margin in the first stage of the production chain (forest management), a $48 \%$ profit margin in the second stage (harvesting), and $54 \%$ in the third stage (sawmilling). However, this analysis, based on a national sample of 30 cases, found that CFEs received higher profit margins of approximately $78 \%$

in the first stage than the $41 \%$ in the second stage.

Production costs and harvesting profits. This study found that forest management costs $\left(\$ / \mathrm{m}^{3}\right)$ and harvesting costs $\left(\$ / \mathrm{m}^{3}\right)$ were associated negatively and significantly with harvesting profits $\left(\$ / \mathrm{m}^{3}\right)$ (Table 5). The average forest management cost was $209 \$ / \mathrm{m}^{3}$ (16 USD/m ${ }^{3}$ ) (Table A.2.1). Cubbage et al. (2013) reported that the average forest management cost in other countries was $2.8 \mathrm{USD} / \mathrm{m}^{3}$, so they note the forest management cost of Mexican CFEs are quite high. The average stumpage revenue was 662 $\$ / \mathrm{m}^{3}$ (51 USD $/ \mathrm{m}^{3}$ ), so the average profits of forest management were $453 \$ / \mathrm{m}^{3}\left(35 \mathrm{USD} / \mathrm{m}^{3}\right)$. Cubbage et al. (2010) found that the average income stumpage in several countries was $40 \mathrm{USD} / \mathrm{m}^{3}$, so in a more recent study, Cubbage et al. (2013) shows that average stumpage income in Mexico is high, which

explains the profits in the first stage of production.

Regarding harvesting costs $\left(\$ / \mathrm{m}^{3}\right)$, this analysis finds that they were on average $490 \$ / \mathrm{m}^{3}\left(38 \mathrm{USD} / \mathrm{m}^{3}\right)$ (Table A.3.2); Cubbage et al. (2013) also note that they are relatively high compared to the harvesting costs of other countries, which range from 12 $\mathrm{USD} / \mathrm{m}^{3}$ to $52 \mathrm{USD} / \mathrm{m}^{3}$. This analysis finds that the average harvesting income was $929 \$ / \mathrm{m}^{3} \quad$ (71 $\mathrm{USD} / \mathrm{m}^{3}$ ), and subtracting the forest management cost and harvesting cost, the average harvesting profits were $230 \$ / \mathrm{m}^{3}$ (18 USD $/ \mathrm{m}^{3}$ ) (Table A.3.2). However, Cubbage et al. (2013) reported that there were losses averaging $75 \$ / \mathrm{m}^{3}$ (6 USD $/ \mathrm{m}^{3}$ ) in this second stage of production. In fact, Cubbage et al. (2013) note that the forest management costs and harvesting costs are high in these two stages of the production chain and income, too. Therefore, Mexican CFEs obtain significant profits in the domestic market and are profitable, but are not competitive in the international market.

UCFR and production costs. At the sample level, the study finds that the volume sold $\left(\mathrm{m}^{3} /\right.$ year) was associated negatively and significantly with production costs $\left(\$ / \mathrm{m}^{3}\right)(\beta=-.033, \mathrm{p}<.01)$; and the timber production area under forest management (ha) was associated positively with production costs $\left(\$ / \mathrm{m}^{3}\right) \quad(\beta=.017)$ (Table 6). These results are consistent with the results Cubbage et al. (2013).
UCFR and harvesting profits. In general, this study found that the volume harvested $\left(\mathrm{m}^{3} / \mathrm{ha}\right)$, was associated positively and significantly with harvesting profits $\left(\$ / \mathrm{m}^{3}\right)(\beta=33.643, p<.01)$. That is, an increase in the volume harvested $\left(\mathrm{m}^{3} / \mathrm{ha}\right)$ results in positive harvesting profits $\left(\$ / \mathrm{m}^{3}\right)$, whereas that, the study Cubbage et al. (2013) does not analyze this relationship and therefore, the result is considered a finding and at the same time, a contribution in explaining the performance of CFEs. Also, Cubbage et al. (2013) report that an increase in the timber production area (ha) decreased harvesting profits $\left(\$ / \mathrm{m}^{3}\right)$; while this study found the opposite, but not significantly. That is, an increase in the timber production area (ha) increased profits $\left(\$ / \mathrm{m}^{3}\right)$ of CFEs. Furthermore, Cubbage et al. (2013), found a positive relationship between volume sold $\left(\mathrm{m}^{3} /\right.$ year $)$ and harvesting profits $\left(\$ / \mathrm{m}^{3}\right)$. This study found the same positive relationship between two variables but not significantly.

At the group level by size of CFE, the analysis found that (1) the volume harvested $\left(\mathrm{m}^{3} / \mathrm{ha}\right)$ was associated positively with harvesting profits $\left(\$ / \mathrm{m}^{3}\right)$ of type III enterprises, while (2) the volume sold $\left(\mathrm{m}^{3} /\right.$ year) was associated positively with harvesting profits $\left(\$ / \mathrm{m}^{3}\right)$ of type IV enterprises, but also the statistical results were not significant and relatively low. However, the results are a first approach to understanding the performance of CFEs and therefore, these can also be considered as another contribution to the study.

With respect to the volume harvested $\left(\mathrm{m}^{3} / \mathrm{ha}\right)$, the group III type had an average of 4,786 hectares; this group harvested an average of $7,301 \mathrm{~m}^{3} /$ year of timber; whereas the group IV type has an average of 8,255 hectares of timber production area under forest management and this group harvested an average of $12,170 \mathrm{~m}^{3} /$ year of timber (Table A.2.1). In fact, the group III type harvested an average of $5 \mathrm{~m}^{3} / \mathrm{ha}$, and the group IV type harvested an average of only 4 $\mathrm{m}^{3} /$ ha. In both groups, small enterprises are harvesting more average timber per hectare; while large enterprises are harvesting less average timber per hectare. This explains why the volume harvested $\left(\mathrm{m}^{3} / \mathrm{ha}\right)$ is significant in the profits of the group III type. Regarding the volume sold $\left(\mathrm{m}^{3} /\right.$ year), as explained in point 4.3.2, the group IV type sells on average $72 \%$ more $\mathrm{m}^{3} /$ year than the group III type, since these also have an average timber production area $72 \%$ greater than the type III enterprises. This explains why the volume sold $\left(\mathrm{m}^{3} /\right.$ year) is very important in the harvesting profits $\left(\$ / \mathrm{m}^{3}\right)$ of type IV enterprises.

According to results in this study, three factors play an important role in the strategy of CFEs: the existence of forest resources, the size of the timber 
production area and efficiency, this last variable was not analyzed in the study, but it is important to mention. In relation to the first, Garibay (2007) argues that $\mathrm{CFE}$ in Mexico maintains strict control and planning of forest land, as business efficiency is a function of having extensive wooded land for a long period of time. Therefore, the system of local governance requires villagers to implement devices to conservation and rational use of forest resources. The study Cubbage et al. (2013) on competitiveness and market access for CFEs in Mexico found that firms with less hectares of timber production area extract more timber per hectare; however, these have considerable stocks of forest resources. They reported that $53 \%$ of the enterprises analyzed are sustainable, because they extracted less timber per year than their annual growth. However, they recommend that some enterprises should consider not exploiting their timber reserves.

Regarding the second, empirical evidence of government of the commons suggests that communities organize to invest in harnessing the resources when these have appropriate dimensions (Segura-Warnholtz 2014; Ostrom 2002). That is, the area should not be so extensive that it entails high costs in defining and controlling borders, but neither so small that it is not possible to generate sufficient flows of product value to the community.

In terms of efficiency, medium type IV enterprises and small type III enterprises had the lowest production costs. This may be due to the fact that, in production areas that are not so large, enterprises can reduce equipment costs and times of mobilization of the workers. However, this does not mean that these are efficient; in fact, comparing the production costs of Mexican medium and small CFEs with production costs of enterprises in other countries, production costs of Mexican CFEs are high (Cubbage et al. 2013). However, Cubbage et al. (2007; 2010) explain that the slow growth of native forests makes wood production costs high. Mexican CFEs sell wood from natural trees, thus enterprises cannot escape this problem.

Vertical integration of the CFE. Considering the contributions of Perry (2005) and the findings of Antinori (2000), we can state that vertical integration arises simultaneously with the creation of the CFE. Vertical integration takes shape under a structure of communal government, which defines the property rights of natural resources and the vertical integration strategy is based in large extensions of land for forest resources and financial control.

Performance of the CFE. According to Barney (1991), internal resources that explain the performance of the enterprise must be valuable, rare, imperfectly imitable and irreplaceable. In this regard, several studies have shown that knowledge resources show the above characteristics to be idiosyncratic and explains the performance of the enterprise (Hatch and Dyer 2004; McEvily and Chakravarthy 2002; Grant 1996; Hall 1993; 1992; Brush and Changanti 1998). However, this study found that, forest resources as tangible resources in part explain the performance of the Mexican CFEs. However is very important to note that, in the context of government of the commons, the governance system determined the property rights, those late have a relationship which the organizational structure and strategy of the community forest enterprise.

\section{Conclusions}

The study analyzed the use and control of forest resources as measured by volume sold $\left(\mathrm{m}^{3} /\right.$ year), volume harvested $\left(\mathrm{m}^{3} / \mathrm{ha}\right)$, and timber production area under forest management (ha) to determine the performance of CFEs in Mexico from theory of firm and new institutional economics perspectives. At the sample level, the volume harvested $\mathrm{m}^{3} / \mathrm{ha}$, was associated positively and significantly with harvesting profits $\$ / \mathrm{m}^{3}$. Whereas, the timber production area (ha) and volume sold $\mathrm{m}^{3} /$ year were associated positively but not significantly with profits $\$ / \mathrm{m}^{3}$ of CFEs. At the group level, the volume harvested $\mathrm{m}^{3} /$ ha was positively associated with harvesting profits $\$ / \mathrm{m}^{3}$ of type III enterprises, whereas volume sold $\mathrm{m}^{3} /$ year was associated positively with harvesting profits $\$ / \mathrm{m}^{3}$ of type IV enterprises. The statistical results were not significant, which suggests definite conclusions cannot be made in general and by size UCFR regression results. However, the results are a first approach to understanding the performance of CFEs vertically integrated under a structure of communal government. Therefore, regarding the performance of CFEs under context of government of commons, it can be explained in part by local governance with rules and norms to conservation and use forest resources from new institutional economics perspective and the vertical integration strategy based on the use and control of forest resources, controlling the production chain and financial resources from theory of the firm, when forest resources as tangible resources are fundamentals in the performance of the Mexican CFE. However, the strategy followed by Mexican CFEs has some implications to be considered in research future, such as pressure on forest resources, fundamentally primary trees, overregulation of natural resources, the failure of individuals to achieve the social optimum for highpriced products. Therefore, there is a high risk in domestic markets and a loss of competitiveness internationally. Given these challenges, this analysis opens up a range of questions and hypotheses for the followers of new institutional economics and theories 
of the firm. Perhaps we are on the threshold of a theory of the firm based on common-pool resources.

Acknowledgements: Special thanks go to AsiaPacific Network for Sustainable Forest Management and Rehabilitation, Beijing Forestry University and Instituto Politécnico Nacional-Mexico that provided financial resources for the project.

\section{References}

1. Antinori C, Rausser GC (2008) Ownership and control in Mexico's community forestry sector. Economic Development and cultural change 57(1):101-136

2. Antinori C (2007) Integración vertical en las empresas forestales comunitarias de Oaxaca. In Bray D, Merino L, Barry D (eds) Los bosques comunitarios de México: manejo sustentable de paisajes forestales, 1ra edn. INESEMARNAT, Mexico, pp 303-342

3. Antinori CM, Bray DB (2005) Community forest enterprises as entrepreneurial firms: economic and institutional perspectives from México. World Dev 33(9):1529-1543. doi:10.1016/j.worlddev.2004.10.011

4. Antinori CM (2000) Vertical integration in Mexican common property forests. Dissertation, University of California

5. Bain J (1954) Economics of scale, concentration, and the conditions of entry in twenty manufacturing industries. Am Econ Rev (44):15-34

6. Barney J (1991) Firm resources and sustained competitive advantage. J Manage 17(1):99-120

7. Barney J (1986) Strategic factor markets: Expectations, luck, and business strategy. Manage Sci 32(10):656-665

8. Bharadwaj SG, Varadarajan PR, Fahy J (1993) Sustainable competitive advantage in service industries: a conceptual model and research propositions. J Marketing 57(4):83-99

9. Boyce JK, Shelly BG (2003). Natural assets: Democratizing environmental ownership. Island Press, Washington, DC

10. Bray DB, Antinori C, Torres-Rojo JM (2006) The Mexican model of community forest management. Forest Policy Econ 8:470-484. doi:10.1016/j.forpol.2005.08.002

11. Bray DB, Merino-Pérez L, Barry D (2005) The community forests of México: Managing for sustainable landscapes. University of Texas Press, Austin, Texas, USA

12. Brush CG, Chaganti R (1999) Businesses without glamour? an analysis of resources on performance by size and age in small service and retail firms. J Bus Venturing 14(3):233-257

13. Caloghirou Y, Kastelli I, Tsakanikas A (2004) Internal capabilities and external knowledge sources: complements or substitutes for innovative performance? Technovation 24(1):29-39. doi:10.1016/S0166-4972(02)00051-2

14. Changhai W, Wen Y, Jing W (2014) The socio-economic effect of the reform of the collective forest rights system in Suthern China: a case of Tonggu County, Jiangxi Province. Small Scale For. doi.org/10.1007/s11842-014-9263-9

15. Coase RH (1960) The problem of social cost. J Law Econ 3(1):1-44

16. Coase RH (1937) The nature of the firm. Economica New Ser 4:386-405

17. Comisión Nacional Forestal (CONAFOR) (2013) Logros y perspectivas del desarrollo forestal en México 2007-2012. Coordinación general de producción y productividad. http://www.conafor.gob.mx:8080/biblioteca/ver.aspx?articulo $=489$

18. Comisión Nacional Forestal (CONAFOR) (2010) Productos maderables certificados, catálogo 2010, México, D. F. FSC. http://www.conafor.gob.mx/biblioteca/Productosmaderables-certificados-Catalogo.pdf

19. Comisión Nacional Forestal (CONAFOR) (2001) Programa estratégico forestal para México 2025. Informe final. http://www.conafor.gob.mx:8080/documentos/ver.aspx?artic ulo $=307 \&$ grupo $=4$
20. Cubbage F, Davis R, Rodríguez PD, Frey G, Mollenhauer R, Kraus EY, González HI, Albarrán HA, Salazar CA, Chemor SD (2013) Competitividad y acceso a mercados de empresas forestales comunitarias en México. http://www.conafor.gob.mx:8080/documentos/docs/22/4807 Competitividad\%20y\%20Acceso\%20a\%20Mercados\%20de $\% 20$ EFC\%20en\%20Mexico.pdf

21. Cubbage F, Koesbanda S, Mac Donagh P, Rubilar R, Balmelli G, Morales OV, De la Torre R, Murara M, Hoeflich VA, Kotze H, Gonzalez R, Carrerro O, Frey G, Adams T, Turner J, Lord R, Huang J, MacIntyre C, McGinley K, Abt R, Phillips R (2010) Global timber investments, wood costs, regulation, and risk. Biomass Bioener 34(12):1667-1678. doi:10.1016/j.biombioe.2010.05.008

22. Cubbage F, Mac Donagh P, Sawinski J, Rubilar R, Donoso P, Ferreira A, Hoeflich V, Morales OV, Ferreira G, Balmelli G, Siry J, Báez M, Alvarez J (2007) Timber investment returns for selected plantations and native forests in South America and the Southern United States. New Forests 33(3):237-255. doi: 10.1007/s11056-006-9025-4

23. Donovan J, Stoian D, Poole N (2008) Global review of rural community enterprises: The long and winding road to creating viable businesses and potential shortcuts. CATIE. http://orton.catie.ac.cr/repdoc/A2720I/A2720I.PDF

24. Food and Agriculture Organization (FAO) (2010) Global forest resource assessment 2010. Main report. http://www.fao.org/docrep/013/i1757e/i1757e.pdf

25. Fudenberg D, Tirole J (2005) Noncooperative game theory for industrial organization: An introduction and overview. In Schmalensee R, Willing RD (eds) Handbook of Industrial Organization volume 1, North-Holland, Amsterdam, The Netherlands, pp 259-328

26. Garibay C (2007) El dilema corporativo del comunalismo forestal. Desacatos, 23:251-274.

27. Gómez I, Méndez E (2007) Association of forest communities of Peten, Guatemala. Context, accomplishments and challenges. http://www.cifor.org/acm/download/pub/grassroot/Peten $\% 20$ guatemala_eng\%20All.pdf

28. Grant RM (1996) Prospering in dynamically-competitive environments: organizational capability as knowledge integration. Organ Sci 7(4):375-387

29. Grant RM (1991) The resource-based theory of competitive advantage: implications for strategy formulation. Calif Manage Rev 33(3):114-135

30. Hall R (1993) A framework linking intangible resources and capabilities to sustainable competitive advantage. Strategic Manage J 14 (8):607-618

31. Hall R (1992) The strategy analysis of intangible resources. Strategic Manage J 13 (2):135-144

32. Hall M, Weiss L (1967) Firm size and profitability. Rev Econ Stat 49(3):319-331

33. Hawawini G, Subramanian V, Verdin P (2003) Is performance driven by industry-or firm-specific factors? a new look at the evidence. Strategic Manage J 24(1):1-16. doi: 10.1002/smj. 278

34. Hansen G, Wernerfelt B (1989) Determinants of firm performance: the relative importance of economic and organizational factors. Strategic Manage J 10(5):399-411. doi: $10.1002 /$ smj.4250100502

35. Hardin G (1968) The tragedy of the commons. Science 62(3859):1243-1248

36. Hatch NW, Dyer JH (2004) Human capital and learning as a source of sustainable competitive advantage. Strategic Manage J 25(12):1155-1178. doi: 10.1002/smj.421

37. Holmstrom BR, Tirole J (2005) The theory of the firm. In Schmalensee R, Willing RD (eds) Handbook of Industria Organization volume 1, North-Holland, Amsterdam, The Netherlands, pp 61-134

38. Harrigan KR (1985) Vertical integration and corporate strategy. Aca Manage J 28(2):397-425

39. Madrid L, Núñez JM, Quiroz G, Rodríguez Y (2009) La propiedad forestal social en México. Investigación ambiental 1(2):179-196 
40. Mahemba CM, De Bruijn EJ (2003) Innovation activities by small and medium-sized manufacturing enterprises in Tanzania. Creativity Inno Manage 12(3):162-173. doi: 10.1111/1467-8691.00279

41. Mahoney JT (1992) The choice of organizational form: vertical financial ownership versus other methods of vertical integration. Strategic Manage J 13(8):559-584

42. Mauri AJ, Michaels MP (1998) Firm an industry effects within strategic management: an empirical examination. Strategic Manage J 19(3):211-219

43. Merino-Pérez L, Segura-Warnholtz G (2005) Forest and conservation policies and their impacts on forest communities in Mexico. In Bray DB, Merino-Pérez L, Barry $\mathrm{D}$ (eds) The community forests of Mexico: Managing for Sustainable Landscapes, University of Texas Press, Austin, Texas, USA, pp 49-69

44. Miller D (2004) Firm's technological resources and the performance effects of diversification: a longitudinal study. Strategic Manage J 25(11):1097-1119

45. Muñoz-Piña C, de Janvry A, Sadoulet E (2003) Recrafting rights over common. Property resources in Mexico. Econ Dev Cult Change 52(1):129-158

46. McDaniel JM (2003) Community-based forestry and timber certification in southeast Bolivia. Small scale For Econ, Manage Policy 2(3):327-341

47. McEvily S, Chakravarthy B (2002) The perspective of knowledge-based advantage: an empirical test for product performance and technological knowledge. Strategic Manage J 23(4):285-375. doi: 10.1002/smj.223

48. McGahan AM, Porter ME (1997) How much does industry matter, really? Strategic Management J 18(S1):15-30. doi: 10.1002/(SICI)1097-0266(199707)18:1+<15::AIDSMJ916>3.0.CO;2-1

49. Nolan TM (2001) Community based forest management: Commercial harvesting of the rainforest of Indonesia. Int For $\operatorname{Rev} 3(3): 231-235$

50. North DC (1990) Institutions, institutional change and economic performance. Cambridge University Press, Cambridge

51. Ostrom E (2002) Reformulating the commons. Ambiente \& Sociedade V(10):1-22

52. Ostrom E (1990) Governing the commons. Cambridge University Press, Cambridge

53. Perry MK (2005) Vertical integration: Determinants and effects. In Schmalensee R, Willing RD (eds) Handbook of Industrial Organization volume 1, North-Holland, Amsterdam, The Netherlands, pp 183-255

54. Porter ME (1985) Competitive advantage: Creating and sustaining superior performance. Free Press, New York

55. Porter ME (1980) Competitive Strategy: Techniques for analysing industries and competitors. Free Press, New York

56. Putz FE, Pinard MA, Fredericksen TS, Peña-Claros M (2004) Forest science and the BOLFOR experience: Lessons learned about natural forest management in Bolivia. In Zarin JD, Alavalapati JR, Putz F, Schmink M (eds) working forests in the neotropics: Conservation through sustainable management? Columbia University Press, New York, 64-96.

57. Prescott JE, Kohli AK, Venkatraman N (1986) The market share-profitability relationship: an empirical assessment of major assertions and contradictions. Strategic Manage J 7(4):377-394

58. Reinganum JF (2005) The timing innovation: research, development and diffusion. In Schmalensee R, Willing RD (eds) Handbook of Industrial Organization volume 1, NorthHolland, Amsterdam, The Netherlands, pp 849-908

59. Restrepo JH, Lopera JF, Rodríguez SM (2007) La integración vertical en el sistema de salud colombiano. Rev Econ Inst 9(17):279-308

60. Rumelt RP (1991) How much does industry matter? Strategic Manage J 12(3):167-185

61. Rumelt RP, Schendel D, Teece DJ (1991) Strategic management and economics. Strategic Manage J 12(winter):5-29
62. Segura-Warnholtz G (2014) Quince años de políticas públicas para la acción colectiva en comunidades forestales. Rev Mex Sociol 76(5):105-135

63. Secretaría de Medio Ambiente y Recursos Naturales-Instituto Nacional de Ecología y Cambio Climático (SEMARNATINECC) 2012 México uinta comunicación nacional ante la Convención Marco de las Naciones Unidas sobre el cambio climático. INECC, México, D. F http://www2.inecc.gob.mx/publicaciones/download/685.pdf

64. Secretaría de Medio Ambiente y Recursos Naturales (SEMARNAT) 2014 Anuario estadístico de la producción forestal 2014. Dirección general de gestión forestal y de suelos. Dirección del registro y del sistema nacional de gestión forestal. México, D. F. http://www.semarnat.gob.mx/sites/default/files/documentos/f orestal/anuarios/anuario_2013.pdf

65. Schlager E, Ostrom E (1992) Property-rights regimes and natural resources: A conceptual analysis. Land Economics 68(3):249-262

66. Scherr SJ, White A, Kaimowitz D (2003) A new agenda for conservation and poverty reduction. Making markets work for low-income producers. Forest Trends, CIFOR, Washington, D. $\mathrm{C}$ http://www.cifor.org/publications/pdf_files/Books/A\%20Ne w\%20Agenda.pdf

67. Schroeder RG, Bates KA, Junttila MA (2002) A resourcebased view of manufacturing strategy and the relationship to manufacturing performance. Strategic Manage J 23(2):105117. doi: $10.1002 / \mathrm{smj} .213$

68. Shen J, Han X, Wen Y, Xie Y (2013) Comparison of the forest tenure in Brazil and China. Can Soc Sci 9(6):94-99

69. Shen Y, Zhnag Y, Xu X, Zhu Z, Jiang C (2009) Towards decentralization and privatization of China's collective forestlands. Int For Rev 11(4):28-35 doi.org/10.1505/ifor.11.4.456

70. Schmalensee R (1985) Do markets differ much. Am Econ Rev 75(3):341-351

71. Schmalensee R, Willig RD (2005) Handbook of Industrial Organization volume 1, North-Holland, Amsterdam, The Netherlands

72. Stoian D, Donovan J (2010) Poverty-environment dividends of rural community enterprises: insights from a cross-sectoral study in Latin America and the Caribbean. CATIE. http://orton.catie.ac.cr/repdoc/A7713I/A7713I.PDF

73. Stone R, D'Andrea C (2001) Tropical forests and the human spirit: journeys to the brink of hope. University of California Press. Bekerley and Los Angeles, USA

74. Tirole J (1989) The theory of industrial organization, MIT Press Cambridge, Cambridge MA

75. Villavicencio G, Hansen E, Bliss J (2012) Factors impacting marketplace success of community forest enterprises: The case of TIP muebles, Oaxaca, Mexico. Small-scale For 11(3):339-363. doi: 10.1007/s11842-011-9188-5

76. Williamson OE (1981) The economics of organizations: the transaction cost approach. The Am J Sociol 87(3):548-577

77. Williamson OE (1975) Markets and hierarchies: analysis and antitrust implications. Free Press, New York

78. Wilshusen PR (2003) Negotiating devolution: community conflict, structural power, and local forest management in Quintana Roo, Mexico. Dissertation, University of Michigan

79. Wiklund J, Shepherd D (2003) Knowledge-based resources, entrepreneurial orientation, and the performance of small and medium-sized businesses. Strategic Manage J 24(13):13071314. doi: $10.1002 / \mathrm{smj} .360$

80. White A, Martin A (2002) Who owns the world's forests? Forest tenure and public forests in transition. Forest Trends, Center for International Environmental Law, Washintong, D.C.

81. http://www.forest-trends.org/documents/files/doc_159.pdf

82. Xie Y, Wen Y, Zhang Y, Li X (2013) Impact of property rights reform on household forest management investment: an empirical study of southern China. Forest Policy Econ 34:73-78. doi:10.1016/j.forpol.2012.12.002 
83. Yli-Renko H, Autio E, Sapienza HJ (2001) Social capital, knowledge acquisition, and knowledge exploitation in young technology-based firms. Strategic Manage J 22(6):587-613. doi: $10.1002 / \mathrm{smj} .183$

84. Zhang Y, Uusivuori J, Kuuluvainen (2000) Impacts of economic reforms on rural forestry in China. Forest Policy Econ 1(1):27-40

85. Zhang Y (2002) The impacts of economic reform on the efficiency of silviculture: a non-parametric approach. Environ Dev Econ 7(1):107-122 